\title{
Effect of Mulching and Planting Geometry on Seed Production of Bell Pepper (Capsicum annuum L.) in Mid-hills of Himachal Pradesh
}

\author{
Rohit Verma, D. K. Mehta, K. S. Thakur, Heerendra Prasad*and Mahonar Lal
}

Dr. Y. S. Parmar University of Horticulture and Forestry, Nauni, Solan, Himachal Pradesh (173 230), India

\section{Article History}

Manuscript No. AR1617

Received in $16^{\text {th }}$ June, 2016

Received in revised form $28^{\text {th }}$ September, 2016

Accepted in final form $4^{\text {th }}$ October, 2016

\section{Correspondence to}

"E-mail: heerendrasagar@gmail.com

\section{Keywords}

Bell pepper, capsicum, mulch, planting geometry, Solan Bharpur

\begin{abstract}
The present experiment was carried out at Dr. Yashwant Singh Parmar University of Horticulture and Forestry, Nauni, Solan, Himachal Pradesh (India) during kharif season 2013 to study the Effect of mulching and planting geometry on seed production in bell pepper (Capsicum annuum L.) in mid-hills of Himachal Pradesh. The planting geometry consists of row layouts and plant layouts. The treatment combinations comprised of four different mulches viz., no mulch, black-plastic mulch, silver-black plastic mulch (upper side of mulch is silver while lower side is black and crop residue mulch, three row layouts with constant population of 37037 plants ha-1 were recommended single row $60 \times 45 \mathrm{~cm}^{2}$ (single rows $60 \mathrm{~cm}$ apart and plants within rows are $45 \mathrm{~cm}$ apart, double row $(75+45) \times 45 \mathrm{~cm}^{2}, 75$ $\mathrm{cm}$ between two double rows, $45 \mathrm{~cm}$ within two double rows and plants within rows are $45 \mathrm{~cm}$ apart, and double row $(90+30) \times 45 \mathrm{~cm}^{2}(90 \mathrm{~cm}$ between two double rows, $30 \mathrm{~cm}$ within two double rows and plants within rows are $45 \mathrm{~cm}$ apart, and two plant layouts viz., rectangle/square, and triangle. The treatment combination of silver-black plastic mulch, double row $(75+45) \times 45 \mathrm{~cm}^{2}$ and triangle method of planting was found superior over all other treatments in terms of growth characters, fruit and seed yield characters.
\end{abstract}

\section{Introduction}

The Bell pepper (Capsicum annuum L.) is one of the important cash crops of mid hill zone of Himachal Pradesh. Bell pepper has attained a status of high value crop in India in recent years and occupies a pride of place among vegetables in Indian cuisine because of its delicacy and pleasant flavour coupled with rich content of ascorbic acid, other vitamins and minerals (Agarwal et al., 2007). The Production of bell pepper in India is very low as compared to the other countries, which may be due to the non-availability of quality seed, inadequate quality inputs and lack of knowledge about the modern agro techniques. Mulching and planting geometry are the important aspects of seed production technology of bell pepper which possess the capability of increasing the quality seed yield. Numerous workers have given reasonable proof that most of the mulches whether organic or synthetic type used in crop production are helpful in reducing disease incidence, controlling in weed population, reducing the impact of falling rain drops, regulation of soil temperature and conservation of soil moisture (Aggarwal et al., 2003; Singh et al., 2006). Moreover, organic mulching materials are also known to be beneficial through their contribution to more moisture retention in the root zone depth and improvement in other physical quality of soil, supplying most of the plant nutrient elements and enhanced growth, yield and quality of crop and their produce (Verma et al., 2005). Planting geometry (row layout and plant layout) determines the plant distribution in the field and thereby affects competition among crop plants for minerals, nutrients and also important to facilitate aeration and light penetration into crop canopy which ultimately influence the yield and quality of produce. Plant arrangement has received relatively little attention particularly in bell pepper. However, limited research has been concerned regarding different types of mulches and planting geometry used to increase fruit and seed production in bell pepper. Therefore, the present experiment was conducted to study the effects of different types of mulches and planting geometry on seed production of bell pepper.

\section{Materials and Methods}

The field experiment was conducted at experimental farm of 
Department of Seed Science and Technology, Dr. Y.S. Parmar University of Horticulture and Forestry, Nauni, Solan, (HP) during kharif season 2013. The soil texture of experimental field is loam to clay loam having $\mathrm{pH}$ ranging from 6.85-7.05. Treatments were combinations of four mulch types, three row layouts and two plant layouts. Mulch types (M) were no mulch $\left(M_{1}\right)$, black-plastic mulch $\left(M_{2}\right)$, silver-black plastic mulch (upper side of mulch is silver while lower side is black, $\mathrm{M}_{3}$ ) and crop residue mulch $\left(\mathrm{M}_{4}\right)$, three row layouts (L) with constant population of 37037 plants ha' ${ }^{-1}$ were, single row $60 \times 45 \mathrm{~cm}^{2}$ (single rows $60 \mathrm{~cm}$ apart and plants within rows are $45 \mathrm{~cm}$ apart, $\left.\mathrm{L}_{1}\right)$, double row, $(75+45) \times 45 \mathrm{~cm}^{2}(75 \mathrm{~cm}$ between two double rows, $45 \mathrm{~cm}$ within two double rows and plants within rows are $45 \mathrm{~cm}$ apart, $\left.\mathrm{L}_{2}\right)$ and double row, $(90+30) \times 45 \mathrm{~cm}^{2}$ ( $90 \mathrm{~cm}$ between two double rows, $30 \mathrm{~cm}$ within two double rows and plants within rows are $45 \mathrm{~cm}$ apart, $\mathrm{L}_{3}$ ) and two plant layouts $(\mathrm{P})$ were rectangle/square $\left(\mathrm{P}_{1}\right)$, and triangle $\left(\mathrm{P}_{2}\right)$. Treatments were arranged in split-split plot design with mulching as main plot, row layout as sub plot and plant layout as sub-sub plot. Plastic mulches were laid in the experimental field by hand, one day before transplanting date while the crop residue mulch was applied one month after transplanting. On $11^{\text {th }}$ April, 2013 forty five days old seedlings of bell pepper variety Solan Bharpur were transplanted by making holes of $5 \mathrm{~cm}$ diameter on the plastic film as the treatments ${ }^{-1}$ in a plot having size of $2.25 \times 2.4 \mathrm{~m}^{2}$ i.e., $5.4 \mathrm{~m}^{2}$ and the treatments were replicated three times. The data were recorded on different growth and yield characters and subjected to statistical analysis using Analysis of Variance (ANOVA) technique.

\section{Results and Discussion}

\subsection{Main effect of mulch on growth characters}

Data presented in (Table 1) revealed that use of silver-black plastic mulch $\left(\mathrm{M}_{3}\right)$ significantly increased the plant height $(73.99 \mathrm{~cm})$ this may be due to no weeds population, better soil moisture retention, optimum root zone temperature and better nutrient availability to the plants. These results are in agreement with Diaz-Perez (2010) and Dickerson (2012). Silver-black plastic mulch $\left(\mathrm{M}_{3}\right)$ took minimum days to first picking (103.50 days). It may be attributed to early flowering due to improved crop growth as evident from plant height; similar finding was also recorded by Bhujbal et al. (2015) in Tomato.

\subsection{Main effect of mulch on fruit and seed yield characters}

Data presented in (Table 1) showed that, fruit and seed yield attributing characters were significantly influenced by the use of mulches. Highest ripe fruit weight $(55.22 \mathrm{~g})$ was obtained with silver-black plastic mulch $\left(\mathrm{M}_{3}\right)$. This could be due to increased biochemical activities in the soil, reduction of evaporation leading to higher soil moisture content, reduction in weed growth and better nutrient availability to the plants. Similar findings were also recorded by Ogutu (2006) and Belel (2012). Maximum number of fruits plant ${ }^{-1}$ (17.81) was obtained with silver-black plastic mulch $\left(\mathrm{M}_{3}\right)$. This might have been attributed due to better weed control, less nutrient loss through leaching, favourable soil temperature and enhanced activities of micro organisms in the soil due to higher moisture level, resulting in increased fruit bearing nodes. The results are in agreement with the report of Hutton and Handley (2007) and Ashrafuzzaman et al. (2011). Maximum ripe fruit yield ha $^{-1}(290.20$ q) was recorded with silver-black plastic mulch $\left(\mathrm{M}_{3}\right)$, which were probably because in silver-black plastic mulch higher photosynthetically active radiation (PAR) being reflected back into plant canopy, increased physiological activities, less nutrient loss through leaching, optimum root zone temperature and better nutrient availability to the plants for overall increase in crop yield. Similar results were also observed by Kapoor (2012). Maximum seed yield (528.08 $\mathrm{kg} \mathrm{ha}^{-1}$ ) was recorded when the plots were mulched with silver-black plastic $\left(\mathrm{M}_{3}\right)$, which may be due to more number of fruits plant ${ }^{-1}$, highest fruit weight and maximum ripe fruit yield recorded with silver-black plastic mulch $\left(\mathrm{M}_{3}\right)$ and these factors increased the seed yield. The results are in agreement with the report of Osman and George (1984), who reported that, when open pollinated plants are harvested for seed, seed yields tend to be proportional to fruit yield.

\subsection{Main effect of row layout on growth characters}

Data presented in (Table 1) showed that double row $(75+45) \times 45 \mathrm{~cm}^{2}\left(\mathrm{~L}_{2}\right)$ method of row layout significantly increased the plant height $(66.92 \mathrm{~cm})$. This may be due to the availability of optimum space where plants were able to exploit more nutrients from the soil and light sources from the environment. These results are in agreement with Ganjare et al. (2013). The earliest fruiting (105.66 days) was recorded with double row $(75+45) \times 45 \mathrm{~cm}^{2}\left(\mathrm{~L}_{2}\right)$ which may be because of availability of sufficient nutrients and light to the plant due to optimum spacing resulting in accumulation of maximum photosynthates and induction of early flowering. The results are in conformity with Islam et al. (2011).

\subsection{Main effect of row layout on fruit and seed yield characters}

A perusal of data presented in (Table 1) revealed that increased number of fruits plant ${ }^{-1}(16.19)$ was obtained with double row $(75+45) \times 45 \mathrm{~cm}^{2}\left(\mathrm{~L}_{2}\right)$, which may be due to better growth of plants because of optimum spacing between plants, resulting in less inter and intra plant competition for nutrients, water and light. It is in line with the findings of Ganjare et al. (2013) and Mantur et al. (2007). Enhanced fruit weight $(54.97 \mathrm{~g})$ was recorded with double row $(75+45) \times 45 \mathrm{~cm}^{2}\left(\mathrm{~L}_{2}\right)$, this could be due to the increased uptake of more nutrients and build up 


\begin{tabular}{|c|c|c|c|c|c|c|}
\hline \multirow[t]{2}{*}{ Particulars } & \multicolumn{6}{|c|}{ Characters } \\
\hline & $\begin{array}{c}\text { Plant height }(\mathrm{cm}) \\
\text { final harvest }\end{array}$ & $\begin{array}{l}\text { Days to ripe } \\
\text { fruit harvest }\end{array}$ & $\begin{array}{l}\text { Number of ripe } \\
\text { fruits plant }{ }^{-1}\end{array}$ & $\begin{array}{l}\text { Ripe fruit } \\
\text { weight }(g)\end{array}$ & $\begin{array}{l}\text { Ripe fruit yield } \\
\text { ha }^{-1}(\mathrm{q})\end{array}$ & $\begin{array}{c}\text { Seed yield } \\
\mathrm{ha}^{-1}(\mathrm{~kg})\end{array}$ \\
\hline \multicolumn{7}{|c|}{ Main effect ( Mulch) } \\
\hline $\mathrm{M}_{1}$ & 48.60 & 109.83 & 10.55 & 52.02 & 159.99 & 248.19 \\
\hline $\mathrm{M}_{2}$ & 69.58 & 105.83 & 17.60 & 54.57 & 281.80 & 508.19 \\
\hline $\mathrm{M}_{3}$ & 73.99 & 103.50 & 17.81 & 55.22 & 290.20 & 528.08 \\
\hline $\mathrm{M}_{4}$ & 69.78 & 106.77 & 15.27 & 54.24 & 242.30 & 416.67 \\
\hline $\mathrm{SEm} \pm$ & 0.45 & 0.22 & 0.30 & 0.40 & 1.58 & 2.83 \\
\hline $\mathrm{CD}(p=0.05)$ & 1.56 & 0.76 & 1.06 & 1.38 & 5.46 & 9.79 \\
\hline \multicolumn{7}{|c|}{ Main effect (Row layout) } \\
\hline $\mathrm{L}_{1}$ & 65.71 & 106.41 & 15.17 & 54.30 & 242.34 & 420.29 \\
\hline $\mathrm{L}_{2}$ & 66.92 & 105.66 & 16.19 & 54.97 & 261.47 & 465.41 \\
\hline $\mathrm{L}_{3}$ & 63.84 & 107.37 & 14.56 & 52.77 & 226.91 & 390.15 \\
\hline $\mathrm{SEm} \pm$ & 0.38 & 0.21 & 0.21 & 0.23 & 1.50 & 2.17 \\
\hline $\mathrm{CD}(p=0.05)$ & 1.14 & 0.44 & 0.65 & 0.702 & 4.52 & 6.52 \\
\hline \multicolumn{7}{|c|}{ Main effect (Plant layout) } \\
\hline $\mathrm{P}_{1}$ & 65.14 & 106.72 & 15.11 & 53.63 & 239.75 & 415.98 \\
\hline $\mathrm{P}_{2}$ & 65.84 & 106.25 & 15.50 & 54.40 & 247.40 & 434.58 \\
\hline $\mathrm{SEm} \pm$ & 0.18 & 0.07 & 0.17 & 0.19 & 1.49 & 2.29 \\
\hline $\mathrm{CD}(p=0.05)$ & 0.53 & 0.21 & NS & 0.56 & 4.36 & 6.69 \\
\hline
\end{tabular}

$\mathrm{M}_{1}$ : No mulch; $\mathrm{M}_{2}$ : Black plastic mulch; $\mathrm{M}_{3}$ : Silver-black plastic mulch; $\mathrm{M}_{4}:$ Crop residue mulch; $\mathrm{L}_{1}$ : Single row $60 \times 45 \mathrm{~cm}^{2} ;$ $\mathrm{L}_{2}$ : Double row $(75+45) \times 45 \mathrm{~cm}^{2} ; \mathrm{L}_{3}$ : Double row $(90+30) \times 45 \mathrm{~cm}^{2} ; \mathrm{P}_{1}:$ Rectangle/Square plant layout; $\mathrm{P}_{2}:$ Triangle plant layout

of sufficient photosynthates enabling the increase in size of fruits (length and breadth), ultimately resulted in the increased fruit weight. Similar findings were also recorded by Islam et al. (2011). The maximum ripe fruit yield $\left(261.47 \mathrm{q} \mathrm{ha}^{-1}\right)$ was obtained with double row $(75+45) \times 45 \mathrm{~cm}^{2}\left(\mathrm{~L}_{2}\right)$, which may be due to the reason that optimum spacing facilitated the plant to develop more rapidly with less inter and intra plant competition for utilizing the available resources from soil and aerial space resulting higher yield. Similar results were also observed by Ganjare et al. (2013). The highest seed yield (465.41 $\left.\mathrm{kg} \mathrm{ha}^{-1}\right)$ was recorded with double row $(75+45) \times 45 \mathrm{~cm}^{2}\left(\mathrm{~L}_{2}\right)$. This may be because of maximum number of fruits plant ${ }^{-1}$ and highest fruit yield ha ${ }^{-1}$ was obtained with double row $(75+45) \times 45 \mathrm{~cm}^{2}$ $\left(\mathrm{L}_{2}\right)$ as compared to other treatments of row layout, resulting in higher seed yields. These results are in conformity with the findings of Dilipkumar and Malabasari (2014).

\subsection{Main effect of plant layout on growth characters}

The data presented in (Table 1) showed that triangle $\left(\mathrm{P}_{2}\right)$ plant layout led to improved plant height $(65.84 \mathrm{~cm})$ and took minimum number of days to fruit harvest (106.25 days), this may be because triangle $\left(\mathrm{P}_{2}\right)$ plant layout reduce the inter and intra plant competition for nutrients, water and light which results in higher plant growth.

\subsection{Main effect of plant layout on fruit and seed yield} characters

The data depicted in (Table 1) showed that triangle $\left(\mathrm{P}_{2}\right)$ plant layout has maximum fruit weight (54.40 g), fruit yield (247.40 quintals $\left.\mathrm{ha}^{-1}\right)$ and seed yield $\left(434.58 \mathrm{~kg} \mathrm{ha}^{-1}\right)$ this is because triangle $\left(\mathrm{P}_{2}\right)$ plant layout may optimise canopy exposure to light and by providing a more uniform area for water and mineral uptake by the roots which enhance the growth characters and maximize the fruit and seed yield as compared with standard rectangular plant layout. The results are in line with Stoffella and Bryan (1988) they reported that plant arrangement has a pronounced influence on plant development and growth of bell pepper and this ultimately affected the yield and quality of produce. However, the main effect of plant layout on number of fruits plant ${ }^{-1}$ was found to be non-significant.

3.7. Interaction effect of mulching, row layout and plant layout

A perusal of data presented in (Table 2) revealed that maximum 
plant height $(75.26 \mathrm{~cm})$, earliest ripe fruit harvesting $(102.33$ days), maximum ripe fruit yield ha- ${ }^{-1}(326.90 \mathrm{q})$, maximum seed yield ha-1 $(614.81 \mathrm{~kg})$ were recorded when the treatment combination of silver-black plastic mulch, double row $(75+45) \times 45 \mathrm{~cm}^{2}$ and triangle plant layout $\left(\mathrm{M}_{3} \mathrm{~L}_{2} \mathrm{P}_{2}\right)$ were used, which might be due to the interaction of benefits of silver-black plastic mulch (higher photosynthetically active radiation (PAR) being reflected back into plant canopy, better weed control, optimum root zone temperature and better nutrient availability to the plants), double row $(75+45) \times 45 \mathrm{~cm}^{2}$ (optimum spacing led to better growth of plants because of less inter and intra plant competition for nutrients, water and light) and triangle plant layout (may optimise canopy exposure to light and by providing a more uniform area for water and mineral uptake by the roots), however number of ripe fruit plant ${ }^{-1}$ and ripe fruit weight was recorded non significant due to interaction effect of mulching row layout and plant layout $\left(\mathrm{M}_{3} \mathrm{~L}_{2} \mathrm{P}_{2}\right)$.

\subsection{Effect of mulching, row layout and plant layout on benefit:} cost ratio

The benefit: cost ratio was significantly influenced by the mulching, row layout and plant layout as presented in (Table 3).

Table 2: Interaction effect of mulching, row layout and plant layout $(\mathrm{M} \times \mathrm{L} \times \mathrm{P})$ on growth characters, fruit and seed yield of bell pepper cv. Solan Bharpur

\begin{tabular}{|c|c|c|c|c|c|c|}
\hline \multirow[t]{2}{*}{ Particulars } & \multicolumn{6}{|c|}{ Characters } \\
\hline & $\begin{array}{c}\text { Plant height }(\mathrm{cm}) \\
\text { final harvest }\end{array}$ & $\begin{array}{l}\text { Days to ripe } \\
\text { fruit harvest }\end{array}$ & $\begin{array}{l}\text { No. of ripe fruits } \\
\text { plant }^{-1}\end{array}$ & $\begin{array}{l}\text { Ripe fruit } \\
\text { weight (g) }\end{array}$ & $\begin{array}{l}\text { Ripe fruit yield } \\
\text { ha }^{-1}(\mathrm{q})\end{array}$ & $\begin{array}{c}\text { Seed yield } \\
\mathrm{ha}^{-1}(\mathrm{~kg})\end{array}$ \\
\hline \multicolumn{7}{|c|}{ Interaction Mulching $\times$ row layout $\times$ plant layout $(\mathrm{M} \times \mathrm{L} \times \mathrm{P})$} \\
\hline $\mathrm{M}_{1} \mathrm{~L}_{1} \mathrm{P}_{1}$ & 49.03 & 109.33 & 11.00 & 52.48 & 169.87 & 259.94 \\
\hline $\mathrm{M}_{1} \mathrm{~L}_{1} \mathrm{P}_{2}$ & 49.33 & 109.00 & 10.66 & 52.72 & 165.92 & 256.59 \\
\hline $\mathrm{M}_{1} \mathrm{~L}_{2} \mathrm{P}_{1}$ & 49.33 & 108.33 & 10.77 & 52.78 & 165.92 & 258.39 \\
\hline $\mathrm{M}_{1} \mathrm{~L}_{2} \mathrm{P}_{2}$ & 50.13 & 108.00 & 11.11 & 52.98 & 169.87 & 269.96 \\
\hline $\mathrm{M}_{1} \mathrm{~L}_{3} \mathrm{P}_{1}$ & 45.60 & 112.33 & 9.55 & 50.54 & 143.20 & 217.23 \\
\hline $\mathrm{M}_{1} \mathrm{~L}_{3} \mathrm{P}_{2}$ & 48.16 & 112.00 & 10.22 & 50.62 & 145.18 & 227.05 \\
\hline $\mathrm{M}_{2} \mathrm{~L}_{1} \mathrm{P}_{1}$ & 67.83 & 106.00 & 18.00 & 54.52 & 289.37 & 516.74 \\
\hline $\mathrm{M}_{2} \mathrm{~L}_{1} \mathrm{P}_{2}$ & 70.33 & 105.33 & 17.44 & 54.52 & 278.51 & 500.14 \\
\hline $\mathrm{M}_{2} \mathrm{~L}_{2} \mathrm{P}_{1}$ & 71.16 & 106.00 & 17.66 & 54.59 & 283.45 & 513.57 \\
\hline $\mathrm{M}_{2} \mathrm{~L}_{2} \mathrm{P}_{2}$ & 72.86 & 105.00 & 18.33 & 56.21 & 298.26 & 556.04 \\
\hline $\mathrm{M}_{2} \mathrm{~L}_{3} \mathrm{P}_{1}$ & 68.50 & 107.33 & 17.00 & 53.19 & 267.65 & 475.55 \\
\hline $\mathrm{M}_{2} \mathrm{~L}_{3} \mathrm{P}_{2}$ & 66.83 & 105.33 & 17.22 & 54.42 & 273.57 & 487.11 \\
\hline $\mathrm{M}_{3} \mathrm{~L}_{1} \mathrm{P}_{1}$ & 74.83 & 104.00 & 17.00 & 55.00 & 274.56 & 495.91 \\
\hline $\mathrm{M}_{3} \mathrm{~L}_{1} \mathrm{P}_{2}$ & 73.73 & 104.00 & 17.33 & 56.00 & 286.41 & 519.99 \\
\hline $\mathrm{M}_{3} \mathrm{~L}_{2} \mathrm{P}_{1}$ & 75.20 & 103.00 & 19.00 & 56.25 & 316.05 & 585.97 \\
\hline $\mathrm{M}_{3} \mathrm{~L}_{2} \mathrm{P}_{2}$ & 75.26 & 102.33 & 19.66 & 56.52 & 326.90 & 614.81 \\
\hline $\mathrm{M}_{3} \mathrm{~L}_{3} \mathrm{P}_{1}$ & 72.90 & 103.33 & 16.88 & 54.10 & 270.61 & 473.28 \\
\hline $\mathrm{M}_{3} \mathrm{~L}_{3} \mathrm{P}_{2}$ & 72.00 & 104.33 & 17.00 & 53.50 & 266.66 & 478.51 \\
\hline $\mathrm{M}_{4} \mathrm{~L}_{1} \mathrm{P}_{1}$ & 69.16 & 107.00 & 14.99 & 53.07 & 229.13 & 391.70 \\
\hline $\mathrm{M}_{4} \mathrm{~L}_{1} \mathrm{P}_{2}$ & 71.43 & 106.66 & 15.00 & 56.09 & 244.93 & 421.33 \\
\hline $\mathrm{M}_{4} \mathrm{~L}_{2} \mathrm{P}_{1}$ & 70.16 & 106.66 & 15.33 & 54.22 & 243.94 & 424.29 \\
\hline $\mathrm{M}_{4} \mathrm{~L}_{2} \mathrm{P}_{2}$ & 71.20 & 106.00 & 17.66 & 56.24 & 287.40 & 500.24 \\
\hline $\mathrm{M}_{4} \mathrm{~L}_{3} \mathrm{P}_{1}$ & 67.93 & 107.33 & 14.22 & 52.85 & 223.20 & 379.25 \\
\hline $\mathrm{M}_{4} \mathrm{~L}_{3} \mathrm{P}_{2}$ & 68.83 & 107.00 & 14.44 & 52.99 & 225.18 & 383.20 \\
\hline $\operatorname{SEm} \pm$ & 0.63 & 0.25 & 0.62 & 0.66 & 5.17 & 7.94 \\
\hline $\mathrm{CD}(p=0.05)$ & 1.86 & 0.74 & NS & NS & 15.10 & 23.19 \\
\hline
\end{tabular}

$\mathrm{M}_{1}$ : No mulch; $\mathrm{M}_{2}$ : Black plastic mulch; $\mathrm{M}_{3}$ : Silver-black plastic mulch; $\mathrm{M}_{4}$ : Crop residue mulch; $\mathrm{L}_{1}$ : Single row $60 \times 45 \mathrm{~cm}^{2}$; $\mathrm{L}_{2}$ : Double row $(75+45) \times 45 \mathrm{~cm}^{2} ; \mathrm{L}_{3}$ : Double row $(90+30) \times 45 \mathrm{~cm}^{2} ; \mathrm{P}_{1}:$ Rectangle/Square plant layout; $\mathrm{P}_{2}$ : Triangle plant layout 
Highest benefit: cost ratio (3.04:1) was obtained with silverblack plastic mulch, double row $(75+45) \times 45 \mathrm{~cm}^{2}$ and triangle plant layout $\left(\mathrm{M}_{3} \mathrm{~L}_{2} \mathrm{P}_{2}\right)$, this was due to less expenditure on labour due to checking of weed growth by silver-black plastic mulch and also highest seed yield was recorded in this

Table 3: Effect of mulching, row layout and plant layout $(\mathrm{M} \times \mathrm{L} \times \mathrm{P})$ on benefit: cost ratio of Bell pepper cv. Solan Bharpur

\begin{tabular}{|c|c|c|c|c|}
\hline \multirow{2}{*}{$\begin{array}{l}\text { Parti } \\
\text { culars }\end{array}$} & \multicolumn{4}{|c|}{ Characters } \\
\hline & $\begin{array}{c}\text { Seed yield } \\
\mathrm{ha}^{-1}(\mathrm{~kg})\end{array}$ & $\begin{array}{c}\text { Gross } \\
\text { income (₹) }\end{array}$ & $\begin{array}{l}\text { Net returns } \\
\left(₹ h^{-1)}\right.\end{array}$ & $\begin{array}{c}\text { Benefit: } \\
\text { cost } \\
\text { ratio }\end{array}$ \\
\hline \multicolumn{5}{|c|}{ Interaction Mulching $\times$ row layout $\times$ plant layout $(\mathrm{M} \times \mathrm{L} \times \mathrm{P})$} \\
\hline $\mathrm{M}_{1} \mathrm{~L}_{1} \mathrm{P}_{1}$ & 259.94 & 519886.70 & 207681.60 & $0.65: 1$ \\
\hline $\mathrm{M}_{1} \mathrm{~L}_{1} \mathrm{P}_{2}$ & 256.59 & 513180.00 & 200975.00 & $0.63: 1$ \\
\hline $\mathrm{M}_{1} \mathrm{~L}_{2} \mathrm{P}_{1}$ & 258.39 & 516786.70 & 204581.60 & $0.65: 1$ \\
\hline $\mathrm{M}_{1} \mathrm{~L}_{2} \mathrm{P}_{2}$ & 269.96 & 539920.00 & 227715.00 & $0.72: 1$ \\
\hline $\mathrm{M}_{1} \mathrm{~L}_{3} \mathrm{P}_{1}$ & 217.23 & 434466.70 & 122261.60 & $0.38: 1$ \\
\hline $\mathrm{M}_{1} \mathrm{~L}_{3} \mathrm{P}_{2}$ & 227.05 & 454113.30 & 141908.30 & $0.44: 1$ \\
\hline $\mathrm{M}_{2} \mathrm{~L}_{1} \mathrm{P}_{1}$ & 516.74 & 1033480.00 & 729918.90 & $2.40: 1$ \\
\hline $\mathrm{M}_{2} \mathrm{~L}_{1} \mathrm{P}_{2}$ & 500.14 & 1000293.00 & 696732.30 & $2.29: 1$ \\
\hline $\mathrm{M}_{2} \mathrm{~L}_{2} \mathrm{P}_{1}$ & 513.57 & 1027153.00 & 723592.30 & $2.37: 1$ \\
\hline $\mathrm{M}_{2} \mathrm{~L}_{2} \mathrm{P}_{2}$ & 556.04 & 1112093.00 & 808532.30 & $2.66: 1$ \\
\hline $\mathrm{M}_{2} \mathrm{~L}_{3} \mathrm{P}_{1}$ & 475.55 & 951106.70 & 647545.60 & $2.12: 1$ \\
\hline $\mathrm{M}_{2} \mathrm{~L}_{3} \mathrm{P}_{2}$ & 487.11 & 974220.00 & 670658.90 & $2.20: 1$ \\
\hline $\mathrm{M}_{3} \mathrm{~L}_{1} \mathrm{P}_{1}$ & 495.91 & 991820.00 & 688258.90 & $2.26: 1$ \\
\hline $\mathrm{M}_{3} \mathrm{~L}_{1} \mathrm{P}_{2}$ & 519.99 & 1039993.00 & 736432.30 & $2.42: 1$ \\
\hline $\mathrm{M}_{3} \mathrm{~L}_{2} \mathrm{P}_{1}$ & 585.97 & 1171940.00 & 868378.90 & $2.85: 1$ \\
\hline $\mathrm{M}_{3} \mathrm{~L}_{2} \mathrm{P}_{2}$ & 614.81 & 1229620.00 & 926058.90 & $3.04: 1$ \\
\hline $\mathrm{M}_{3} \mathrm{~L}_{3} \mathrm{P}_{1}$ & 473.28 & 946566.00 & 643004.90 & $2.11: 1$ \\
\hline $\mathrm{M}_{3} \mathrm{~L}_{3} \mathrm{P}_{2}$ & 478.51 & 957033.30 & 653472.30 & $2.15: 1$ \\
\hline $\mathrm{M}_{4} \mathrm{~L}_{1} \mathrm{P}_{1}$ & 391.70 & 783400.00 & 519636.60 & $1.96: 1$ \\
\hline $\mathrm{M}_{4} \mathrm{~L}_{1} \mathrm{P}_{2}$ & 421.33 & 842660.00 & 578896.60 & $2.19: 1$ \\
\hline $\mathrm{M}_{4} \mathrm{~L}_{2} \mathrm{P}_{1}$ & 424.29 & 848580.00 & 584816.60 & $2.21: 1$ \\
\hline $\mathrm{M}_{4} \mathrm{~L}_{2} \mathrm{P}_{2}$ & 500.24 & 1000487.00 & 736723.30 & $2.78: 1$ \\
\hline $\mathrm{M}_{4} \mathrm{~L}_{3} \mathrm{P}_{1}$ & 379.25 & 758506.70 & 494743.30 & $1.87: 1$ \\
\hline $\mathrm{M}_{4} \mathrm{~L}_{3} \mathrm{P}_{2}$ & 383.20 & 766413.30 & 502649.90 & 1.90:1 \\
\hline $\mathrm{SEm} \pm$ & 7.94 & 15886.50 & 15886.51 & 0.04 \\
\hline $\begin{array}{l}\mathrm{CD} \\
(p=0.05)\end{array}$ & 23.19 & 46381.84 & 46381.88 & 0.15 \\
\hline
\end{tabular}

treatment combination.

\section{Conclusion}

The present studies have demonstrated the benefits of treatment combination silver-black plastic mulch, double row $(75+45) \times 45 \mathrm{~cm}^{2}$ and triangle plant layout $\left(\mathrm{M}_{3} \mathrm{~L}_{2} \mathrm{P}_{2}\right)$ and it was found superior over all other treatments in terms of growth characters, fruit and seed yield characters and had maximum benefit: cost ratio. Thus, we recommended the use of silver-black plastic mulch in combination with double row $(75+45) \times 45 \mathrm{~cm}^{2}$ and triangle plant layout $\left(\mathrm{M}_{3} \mathrm{~L}_{2} \mathrm{P}_{2}\right)$ for commercial cultivation bell pepper after multi-location testing.

\section{References}

Agarwal, A., Gupta, S., Ahmed, Z., 2007. Influence of plant densities on productivity of bell pepper (Capsicum аппиит) under greenhouse in high altitude cold desert of Ladakh. Acta Horticulture 756, 309-314.

Aggarwal, S., Korla, B.N., Raina, J.N., 2003. Effects of mulches on soil hydrothermal Regimes, weed incidence, yield and quality of ginger. Journal of the Indian Society of Soil Science 51, 65-67.

Ashrafuzzaman, M., Halim, M.A., Ismail, M.Z., Shahidullah, S.M., Hossain, A., 2011. Effect of plastic mulch on growth and yield of Chilli (Capsicum annuum L.) Brazilian Archives of Biology and Technology 54(2), 321-330.

Belel, M.D., 2012. Effects of grassed and synthetic mulching materials on growth and yield of sweet pepper (Capsicum annuит L.) in Mubi, Nigeria. Journal of Agriculture and Social Sciences 8(3), 97-99.

Bhujbal, P.D., Tambe, T.B., Ulemale, P.H., 2015. Effects of mulches on flowering, fruiting, yield and pest disease incidence of tomato ( Lycopersicon esculantum M.). The Bioscan 10(1), 465-468.

Diaz-Perez, J.C., 2010. Bell pepper (Capsicum annum L.) grown on plastic film mulches: effects on crop microenvironment, physiological attributes and fruit yield. Hort Science 5(8), 1196-1204.

Dickerson, G.W., 2012. Commercial vegetable production with plastic mulches. Cooperative Extension Service New Mexico State University 245, 1-4.

Dilipkumar, M.R., Malabasari, T.A., 2014. Influence of planting geometry and foliar spray of micronutrients on seed yield of bell pepper (Capsicum annuит L.). International Journal of Informative and Futuristic Research 12(1), 102-106.

Ganjare, H., Futane, N.W., Dagwar, S., Kurhade, K., 2013. Growth and yield characters of capsicum in response to planting distance and sources of nutrients. Scholarly Journal of Agricultural Science 3(9), 386-390.

Hutton, M.G., Handley, D.T., 2007. Effects of silver reflective mulch, white inter-row mulch and plant density on yields of pepper in Maine. Horticulture Technology 17(2), 214-219. 
Islam, M., Saha, S., Akand, H., Rahim, A., 2011. Effect of spacing on the growth and yield of sweet pepper (Capsicum annuum L.). Journal of Central European Agriculture 12(2), 328-335.

Kapoor, P., 2012. Effect of polythene mulches and barrier crops on virus disease incidence and yield of bell pepper. Indian Phytopatholoy 65(4), 391-394.

Mantur, S.M., Patil, H.B., Biradar, S.R., Patil, S.R., Patil, D.R., 2007. Effect of planting geometry and nutrient source for capsicum under shade house during summer and kharif. Karnatka Journal of Agricultural science 20(3), 578-580.

Ogutu, M., 2006. Effects of colored plastic mulches on bell pepper yield and fruit characteristics. Hort Science 41(4), 1075-1076.

Osman, O.A., George, R.A.T., 1984. The effect of mineral nutrition and fruit position on seed yield and quality in sweet pepper (Capsicum annuиm L.). Acta Horticulturae 143, 133-141.

Singh, I.S., Awasthi, O.P., Meena, S.R., 2006. Influence of mulch on hydrothermal regimes, leaf and soil nutrients concentrations, growth and yield of brinjal grown under ecosystem. Agropedology 16, 112-116.

Stoffella, P.J., Bryan, H.H., 1988. Plant population influences growth and yields of bell pepper. Journal of American Society for Horticultural Science 113, 835-839.

Verma, M.L., Sharma, R.K., Bhandri, A.R., 2005. Effect of soil water conservation practices on root growth, yield, nutrient removal and quality of pea and tomato crops. Journal of the Indian Society of soil Science 53, 602-607. 